\title{
V rozhovoru nad rozhovory o pomáhajících profesích s Janem Slavíkem
}

\author{
„Problémy pomáhajících profesí v mezioborových souvislostech“
}

Koncem loňského roku vyšla v nakladatelství Masarykovy univerzity pod editorstvím Vlastimila Švece knížka Profesionální pomáhání. Co na ni ř́íkáte?

Kniha Profesionální pomáhání je pojata jako soubor rozhovorů s pracovníky pomáhajících profesí, kteří vyprávějí o své zkušenosti: chirurg, psychoterapeut, zdravotní sestra, učitelka, trenér... Každý z rozhovorů začíná jakýmsi otevřením dveří do problematiky profese, poté se odvíjí podle logiky zkušenosti a vzpomínek, které do něj dotazovaný odborník přináší.

Ano, kniha nastoluje téma pomáhajících profesí a př́pravy na ně. $V$ jakých ohledech je toto téma důležité?

Pomáhající profese jsou bezesporu hodné úcty všech humánně cítících občanů již díky tomu, co se ozývá hned v prvním slově jejich názvu: pomáhání. Spojení této obecně lidské hodnoty s profesionalitou pak vypovídá o výjimečné zodpovědnosti těchto povolání nebo spíš poslání, protože pomáhat profesionálně, to znamená brát na sebe velký závazek, být obětavě k dispozici, neudělat fatální chybu, zvládat výjimečně obtížné situace apod.

Je toto téma nějak speciálně důležité dnes - tedy v kontextu výzev spojených s epidemií covid-19?

Všechny tyto a mnohé další příznačné rysy pomáhajících profesí v době pandemické krize byly ve hře jako vždy, jen s tím rozdílem, že se náhle objevily $\mathrm{v}$ ohnisku veřejné pozornosti.

Jaké poznatky o pomáhajících profesích bychom potřebovali a může být tato forma jejich získávání - tedy rozhovory - užitečná?

Řekl bych, že bychom měli mít takové poznatky, které by pomáhaly pomáhajícím profesím. Nebo méně neosobně: které by pomáhaly pracovníkům v pomáhajících profesích. K tomu jistě mohou být východiskem rozhovory s nimi, protože oni sami nejlépe vědí, co v jejich práci potřebuje největší podporu a oporu. 
Při „čtení knihou napřič“ vystupuje do popředí téma interdisciplinarity a interprofesionality. Objevuje se v rozhovorech potřeba mezioborové spolupráce pomáhajících profesionálu? Jak by se měla tato témata zhodnotit a rozpracovat? Interdisciplinarita nebo interprofesionalita vyplývá z toho, co je pro všechny tyto obory společné: pomáhání lidem. To znamená, že se vždy musí jednat o řešení $v$ praxi, nezř́idka akutní nebo i rizikové. A praxe je z pohledu specializovaných oborů nesmírně komplexní, protože z ní se vlastně všechny ty rozmanité obory rodily a do ní se znovu a znovu vracejí, aby jí pomáhaly společně, takříkajíc ruku v ruce. $V$ akci pak většinou není čas dumat nad mezioborovou součinností, protože je třeba jednat a dospět k žádoucímu cíli bez velkého rozmýšlení. Proto je velmi důležité, aby se obory, které se podílejí na profesionálním rozhodování v praxi, dorozumívaly včas předem s ohledem na úkoly, které je nutné $\mathrm{s}$ jejich podporou v praxi řešit. Takto nabývané společné poznání by pak měly zhodnocovat během př́pravy pracovníků pomáhajících profesí.

Při „čtení knihou napříč se ukazuje, že profesionálové více či méně operují na vícero a kčních polích - to pro ně může být mnohdy náročnou výzvou. V čem tkví tato náročnost a jak profesionály podporovat, aby ji zvládali?

Tato otázka má více rozměrů, všimnu si jenom jednoho z nich. Pomáhající profese se obracejí $\mathrm{k}$ lidem, proto $\mathrm{v}$ nich nikdy nejde jenom o samotnou věcnou stránku řešení v profesní situaci, ale do nemalé míry též o stránku vztahovou, sociální, lidskou. Ta se v rozhovorech často ozývá. Myslím si, že tento jedinečný doprovod věcného rozhodování představuje zvlášt' náročnou složku odborné práce $v$ pomáhajících profesích. Vzpomeňme jenom na paradoxní problém odporu vůči pomoci: agresivní pacient napadající ošetřujícího lékaře, žák bouřící se proti svému učiteli...

Může něco čtenáře na knížce překvapit?

Překvapení se skrývají takříkajíc na každém rohu během rozhovorů, zejména tehdy, nemají-li sami čtenáři s příslušnou profesí vlastní zkušenost. Zkušení pracovníci pomáhajících profesí totiž čtenářum nabízejí mnoho zajímavých podnětných vhledů a moudrých myšlenek. Možná nejsou v pravém slova smyslu překvapením, protože člověka napadne, „ano, to přece vím, souhlasím, jen jsem na to běžně nepomyslel/a“. Právě proto ale mohou rozhovory otevírat oči a podněcovat citlivost pro důležitá témata, která se týkají každého z nás a jenom každodenní spěch je důvodem, proč se jim nevěnujeme. Je 
dobře, že kniha o pomáhajících profesích dává příležitost pozastavit se u nich a zamyslet se.

Zmíním se ještě konkrétně o jednom milém překvapení v závěru knihy, protože její autor tu vystupuje $\mathrm{z}$ anonymity a sám čtenářům sděluje svůj pohled na pomáhající profese a své zkušenosti z působení v nich.

Je něco, co všechny rozhovory spojuje?

Na mě nejvíce zapůsobilo velké zaujetí pro práci, láska $\mathrm{k}$ profesi a starost o špičkový výkon v tom nejlepším slova smyslu. Také osobité spojení mezi rutinní („naučitelnou“) a uměleckou („nesdělitelnou“) stránkou profese je společné. Tyto kvality prozařují a spojují všechny rozhovory. Spolu s nimi se jakoby mezi řádky - a také já bych velmi nechtěl, aby tu cokoliv vyznělo jako fráze - ve všech rozhovorech prokazuje zřetelná starost o druhé, láska k lidem.

A naopak - je z publikace patrná specifičnost představovaných profesí?

Bezesporu se $\mathrm{v}$ každém rozhovoru zřetelně ukazuje jedinečnost příslušné profese, protože zkušenosti, o nichž dotazovaní vyprávějí, jsou napříč profesemi nezaměnitelné. Každá profese má své výjimečnosti, což platí i pro jemnější diferenciaci uvnitř profesí. Zvažme kupříkladu rozdíl mezi chirurgem a paliatrem (lékařem pečujícím o smrtelně nemocné v posledních fázích života). Oba jsou lékaři, étos jejich výpovědí při rozhovorech je shodný, oba pracují v týmu, ale přesto se jejich klíčová témata v ledasčem důležitém odlišují. Třeba v pojetí dialogu o životních hodnotách. Pro paliatra to nezřídka je prostředek k řešení otázky, zda vůbec vystavit pacienta náročnému působení léčby. Pacientovo „děkuji, nechci“ není výrokem zoufalství, ale racionální uvážlivé rozhodnutí. Pro chirurga je dialog o životních hodnotách spíš nástrojem podpory pacientova odhodlání vynaložit síly pro rehabilitaci apod.

Vyplývá z rozhovorů, že pomáhající profesionály lze považovat za reflektující praktiky?

Ano, mám za to, že všichni dotazovaní jsou reflektujícími praktiky, protože o své práci do hloubky přemýšlejí, hledají poučení v tom, co v ní vyzkoušeli a zažili. Jedna z dotazovaných, zdravotní sestra, přímo říká, že dobrého profesionála charakterizuje schopnost sebereflexe. A dodává: „Bohužel, často se stává, že některé sestry už provádí svou práci rutinně a nereflektují ji. To 
s sebou přináší úskalí, která se nemusí projevit hned." Shodně se vyjadřuje učitelka a vzdělavatelka učitelů: „Prvním předpokladem pro zvládání všech těchto zátěží je pro učitele dovednost analyzovat sebe sama, sebereflexe."

Je z rozhovorů zřejmá nejenom obsahová dimenze profese, ale i osobnost pomáhajících (dotazovaných) profesionálů?

Každý z rozhovorů má „barvu a vůni“, které jsou mu vtištěny osobností jeho autora. Projevuje se v originálních myšlenkách, ve způsobu přemýšlení, v drobných anekdotách vynořujících se ze vzpomínek, které jsou jedinečné a nezaměnitelné. Typicky při vzpomínkách na jednotlivé př́ípady: těžce zraněný chlapec, jehož záchrana si od dotazovaného chirurga vyžádala nasazení všech sil, nebo překvapivé rozuzlení v psychoterapeutově př́běhu léčby rodiny, jejíž zakázka nejprve žádala nápravu synovy touhy po drogách, aby se nakonec ukázalo, že pomoc potřebují především rodiče.

Je z rozhovorů cítit profesionalita dotazovaných? Jak se (např́klad) projevuje? Je zřejmé, že pro rozhovory byli vybráni špičkoví odborníci, takže jejich profesionalita je z výpovědí dostatečně zřejmá. Vysvítá již ze samotného hlubokého zájmu o profesi, který je v rozhovorech zjevný, a kromě toho z řady zdánlivě drobných postřehů a poznatků, které vypovídají o skvělém zvládání profesních činností.

V rozhovorech se k pomáhajícím profesím vyjadřují praktikující profesionálové i odborníci, kteř́ profesi zažili, ale zároveň ji reflektují z teoretických pozic (viz např. rozhovory s M. Píšovou, J. Lorenzovou). Projevuje se zde synergie praktických zkušeností a teorie? V čem to může být prospěšné?

Člověk, který využívá teorii $\mathrm{k}$ náhledu na svou práci, má nespornou výhodu v tom, že má k dispozici specializovaný jazyk, jak se o své práci dorozumět $\mathrm{s}$ druhými. Tato specifická hodnota se $\mathrm{v}$ rozhovorech projevuje zejména tehdy, když se mluví o sdílené a zobecněné zkušenosti, resp. o sdílení a zobecňování zkušenosti.

Co rozhovory otevírají, a co naopak skrývají?

Z fenomenologie víme, že vždy, když se něco odkrývá a ukazuje, jiné se tím skrývá a uniká pozornosti. Jistě to platí i pro poznatky uváděné v těchto rozhovorech. Nicméně myslím, že čtenář sám by měl tato skrytá místa objevovat 
především proto, aby ho tyto objevy inspirovaly k vlastnímu hlubšímu přemýšlení - k odhalování skrytého.

Otázky kladli Tomáš Janík a Vlastimil Švec

\section{Literatura}

Švec, V. (Ed.). (2019). Profesionální pomáhání. Rozhovory např́č pomáhajícími profesemi. Brno: Masarykova univerzita. Dostupné z https://munispace.muni.cz/library/catalog/ view/1441/4035/1949-1/0\#preview 